\title{
Development of a flour for baking based on banana peel (Musa paradisiaca) and chickpea flour (Cicer arietinum)
}

\section{Desarrollo de una harina para panificación a base de cáscara de plátano (Musa paradisiaca) y harina de garbanzo (Cicer arietinum)}

CERÓN-CARRILLO, Teresa Gladys†, SANTIESTEBAN-LÓPEZ, Norma Angélica, MORALESPAREDES, Yesbek Rocío and MALDONADO-RESÉNDIZ, Jorge Ángel

Benémerita Universidad Autónoma de Puebla. Facultad de Administración (Gastronomía), Ciudad Universitaria. Puebla, Pue. México

ID $1^{\text {st }}$ Author: Teresa Gladys, Cerón-Carrillo / ORC ID: 0000-0002-3492-379X, CVU CONACYT ID: 211348

ID $1^{\text {st }}$ Coauthor: Norma Angélica, Santiesteban-López / ORC ID: 0000-0001-7700-4139, CVU CONACYT ID: 240825

ID $2^{\text {nd }}$ Coauthor: Yesbek Rocío, Morales-Paredes / ORC ID: 0000-0003-1740-2682, CVU CONACYT ID: 296456

ID $3^{\text {rd }}$ Coauthor: Jorge Ángel, Maldonado-Reséndiz / ORC ID: 0000-0003-1787-3660

DOI: $10.35429 / J U R R E .2019 .4 .3 .11 .16$

Received March 11, 2019; Accepted June 27, 2019

\begin{abstract}
The progressive increase in the number of people who cannot consume wheat flour leads the bakery industry to think about the use of different ingredients. In addition to this, there is growing concern about the sustainable use of ingredients for food preparation. The objective of this work is the formation of a flour based on banana peel and chickpea flour. Once the banana peel flour was obtained by drying, grinding and sieving it, a pancake was made by varying the mixture of the two flours $(15 / 85 ; 20 / 80 ; 25 / 75$, $30 / 70$ and $35 / 75 \%$ banana flour / chickpea flour), quantifying bread firmness, firm height, weight, moisture, protein, in addition to a sensory evaluation. It is concluded that the mixture with a higher banana peel content has better taste, odor, and texture characteristics than the other preparations. In addition, this flour also has a higher fiber and protein content compared to wheat flour prepreparation. These types of products help increase sustainability in food preparation as well as improving health due to the nutrients it contains.
\end{abstract}

Flour, Banana Peel, Sustainability

\begin{abstract}
Resumen
El aumento progresivo del número de personas que no pueden consumir harina de trigo, lleva a la industria panadera a pensar en el uso diferentes ingredientes. Aunado a esto, se encuentra la creciente preocupación por el uso sustentable de ingredientes para la preparación de alimentos. El objetivo del prsente trabajo es la formaulación de una harina a base de cáscara de plátano y harina de garbanzo. Una vez obtenida las harina de la cáscara de plátano mediante secado, molido y tamizado de la misma, se elaboró un panque variando la mezcla de las ambas harinas $(15 / 85 ; 20 / 80 ; 25 / 75,30 / 70$ y $35 / 75 \%$ de harina de plátano/harina de garbanzo), cuantificando la firmeza del pan, la altura firnal, peso, humedad, proteínas, además de una evaluación sensorial. Se concluye que la mezcla con mayor contenido de cáscara de plátano posee mejores características de sabor, olor, y textura que las demás preparaciones. Además esta harina también posee un mayor contenido de fibra y proteínas en comparación con la preapración a base de harina de trigo. Este tipo de productos ayudan a incrementar la sustentabilidad en la preparación de alimentos así como a la mejora de la salud por los nutrientes que contiene.
\end{abstract}

Harina, Cáscara de plátano, Sustentabilidad

Citation: CERÓN-CARRILLO, Teresa Gladys, SANTIESTEBAN-LÓPEZ, Norma Angélica, MORALES-PAREDES, Yesbek Rocío and MALDONADO-RESÉNDIZ, Jorge Ángel. Development of a flour for baking based on banana peel (Musa paradisiaca) and chickpea flour (Cicer arietinum). Journal-Urban-Rural and Regional Economy. 2019. 3-4: 11-16

\footnotetext{
$\dagger$ Researcher contributing as first author.
} 


\section{Introduction}

Bread in Mexico is part of a culture and tradition. The bakery arises with the arrival of the Spaniards who introduced the wheat, it was then that the Mexicans turned it into flour, to create dough and produce bakery products with a wide variety of shapes, flavors and names.

The white flour, then, was considered the finest and was for consumption by the viceroys, bishops and other people with high incomes, contrary to this, there was the brown flour used to create the pambazo, name that means low bread, bread for the poor (Barros and Buenrostro, 2009)

The bread is still made with wheat flour, which also provides carbohydrates, proteins for which the bread has its organoleptic characteristics. However, as the number of people suffering from disorders related to gluten content increases, these types of products have become unattainable.

This is why different ingredients have been added to replace wheat and that they are also accepted by the consumer. Examples of these are some starches, cereal and pseudocereal flours, hydrcolloids, legumes and proteins. However, many of these products do not have the firmness necessary to generate products with adequate rheological characteristics, so the addition of some flours and emulsifiers is required to improve them (Aguilar et al., 2015).

However, the lack of starch in the preparation of these products has had a negative impact on the consumer's perception, which is why it is necessary to add ingredients such as dietary fiber such as inulin, oligofructose, flaxseed of linseed; in addition to hydrocoyloids used to increase the viscosity of the mass for the retention of gases, thereby improving crumb properties and volume (Pérez-Quirce et al., 2017; Demirkesen et al., 2010)

On the other hand, the innovation and sustainability of food is increasingly seen both in the food industry and in the entrepreneurship of small producers, who have sought the production of food of high nutritional value whose process is friendly to the environment and of minimum
Waste production, likewise, has sought to innovate and experiment with the substitution of ingredients and combination of flavors to create products that arise as alternatives, which are mostly healthier than those commonly known.

Thanks to this it is increasingly common to find a wide variety of alternative products and different components on the market, all designed for the same use; In the bakery industry, products have been developed by replacing flours commonly used with others based on functional foods and / or food wastes for greater fiber intake. Examples of these are the use of orange, pineapple, tangerine, egg and potato peels for fiber enrichment of various products (OcampoOlalde et al., 2015; Rosas et al., 2018)

In addition, legume flours, as well as fruit flours, due to their nutritional and fiber content, are ideal alternatives to improve the nutritional quality of bakery products. Legumes, being an important component of the Mediterranean diet, and due to their high nutritional value, have been the subject of study and experimentation of researchers and people seeking product innovation. Legume meal, in addition to having a high nutritional value, is the functional base of products with low protein intake. (Pourafshar et al., 2015; Jarehis et al., 2015).

For this reason, the objective of this work was to formulate a sponge cake made from chickpea flour and banana peel as a more sustainable and gluten-free alternative.

\section{Materials and methods}

\section{Materials}

Chickpea was compared in a market in the city of Puebla. The banana peel was obtained from an establishment in the city of Puebla. It was also used for the formulation of carboxymethyl cellulose (Deiman, Mexico), sugar (Zulka, Mexico), butter (Chipilo, Mexico), eggs (Tehuacán, Mexico). 


\section{Methodology}

\section{Chickpea flour production}

The dried seeds of garbanazo were ground using a Nutribullet mill (NTBT600, Mexico) so that the particle will pass through a US sieve no. 50 (300 )n) and stored at room temperature $\left(25^{\circ} \mathrm{C}\right)$ in a glass jar.

\section{Banana Peel Flour}

The tabasco banana peel was washed and disinfected with a solution with $10 \mathrm{ppm}$ of sodium hypochlorite and then maintained for 20 minutes in a $2 \%$ citric acid solution. The shell was then dehydrated in a drying oven (Velaquin model 9053A, Mexico) at $98^{\circ} \mathrm{C}$ for 8 hours. The shell was then milled with a Nutribullet mill until the particle passed through a US sieve no. 50, the flour was stored at room temperature and in a glass jar.

\section{Formulation of sponge cake}

The preparation of the cake was carried out by the following process: in a tabletop mixer (Kitchen 5L. Model 5KSM175 Artisan) the butter $(100 \mathrm{~g})$ was beaten until it had a creamy consistency, 3 egg yolks and 100g of sugar were added until obtaining a creamy and homogeneous mixture, then three egg whites were beaten to nougat, then add the banana flour varying the amount $(20,30,40 \mathrm{~g})$, chickpea flour (60, 70 and $80 \mathrm{~g})$, Carboxymethylcellulose (7g), baking powder $2 \mathrm{~g}$. For the preparation of the control cake, $100 \mathrm{~g}$ of wheat hariana and a teaspoon of royal (combination of sodium bicarbonate, tartaric acid and an anti-caking agent) were used and the same process was used. The mixture was divided into 8 molds $5 \mathrm{~cm}$ in diameter and $2.3 \mathrm{~cm}$ high and baked at $180^{\circ} \mathrm{C}$ for 20 minutes.

\section{Chemical Properties of Flour}

Moisture determination was carried out using the gravimetric method using the AOAC 925.10 methodology. The crude protein content was also determined using the Kjeldahl method with the AOAC 2001.11 methodology and multiplying it by a factor of 5.7 to obtain the percentage of proteins, as well as the determination of total fats with the AOAC 31.4.02 methodology.

\section{Physical properties of bread}

The weight, volume and volume specific to each bread was determined. An analytical balance was used for weight measurement (Velaquin VE-303). The volume of the bread was measured by placing each piece of bread in a container with known volume and containing millet seeds, the volume of the bread was recorded as the volume displaced by the piece of bread. The specific volume was recorded as the division of the volume by the weight of each piece of bread.

\section{Sensory Bread Evaluation}

A hedonic bread test was performed after 12 hours after the pieces were taken out of the oven. Tests were carried out to measure color, smell, taste, texture and acceptability in general. The panelists evaluated the formulations of the breads using a hedonic scale of 7 points, 1 being "extremely disliked" and 7 "Extremely liked"

\section{Statistic analysis}

The tests were performed in triplicate. The data obtained were compared using one-way ANOVA using the Minitab v.14 software.

\section{Results and Discussion}

The formulations of the different breads were as follows:

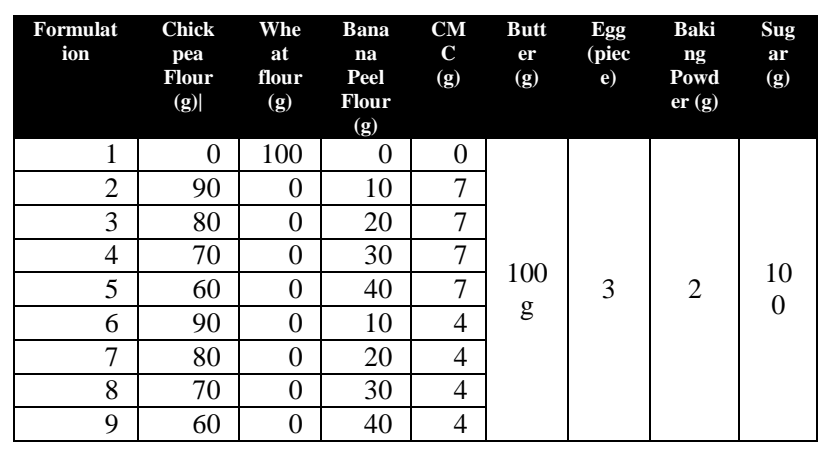

Table 1 Formulation of the different types of breads Source: Self Made

\section{Chemical Properties of Flour}

The combination of the two flours has an aspect similar to whole wheat flour and with a slight banana aroma, they also have a more granular appearance than white wheat flour. 


\begin{tabular}{|l|c|c|c|}
\hline \multicolumn{1}{|c}{ Flour } & \multicolumn{1}{c}{$\begin{array}{c}\text { Proteína } \\
(\mathbf{\%})\end{array}$} & $\begin{array}{c}\text { Grease } \\
(\mathbf{\%})\end{array}$ & $\begin{array}{c}\text { Humidity } \\
(\mathbf{\%})\end{array}$ \\
\hline Chickpea & $21.76+1.21$ & $7.12+0.87$ & $8.32+0.61$ \\
\hline $\begin{array}{l}\text { Banana } \\
\text { peel }\end{array}$ & $7.34+0.73$ & $4.67+0.89$ & $6.52+0.45$ \\
\hline
\end{tabular}

Table 2 Chemical composition of garbanazo flour and banana peel

Source: Self Made

It can be seen that chickpea wheat flour has a higher percentage of protein, fat and moisture than banana flour, however, by incorporating the two flours in a formulation, there are higher concentrations of the three components (Pacheco-Delahaye and Testa, 2005). According to the work done by Gonzalez and Lobo (2010), the antioxidant capacity found in banana peel is higher in relation to the peel of other fruits.

The banana peel also has high water retention capacity values, which proved to be higher compared to the bagasse obtained from other vegetable sources (Grigelmo and Martina, 1999; Alarcon-García, 2003).

\section{Bread Making}

The breads made with the standard mixture had an average height of $7 \mathrm{~cm}$ and had a golden color, the breads with the banana peel formulation had an intense brown color and a slight banana flavor as well as a more grainy than standard consistency.

When the flour was formed with both the dry ingredients and the wet ingredients, it was observed that the dough had a consistency very similar to the dough made with the wheat flour. However, it was observed that with a greater amount of $\mathrm{CMC}$, the consistency of the dough becomes more viscous.

Below are the results obtained for the different measurements that were made to the bread formulations (Table 3 ).

\begin{tabular}{|l|c|c|r|r|}
\hline Formulation & Weight & \multicolumn{1}{c|}{ Height } & Volume & Specific volume \\
\hline 1 & $72.3+1.3$ & $6.5+0.12$ & $25+2$ & $0.346+0.062$ \\
\hline 2 & $73.1+0.8$ & $5.5+0.15$ & $28+3$ & $0.383+0.034$ \\
\hline 3 & $73.6+1.1$ & $5.3+0.21$ & $27+3$ & $0.367+0.041$ \\
\hline 4 & $73.5+0.9$ & $5.1+0.17$ & $28+2$ & $0.381+0.021$ \\
\hline 5 & $74.3+1.5$ & $6.3+0.11$ & $28+1$ & $0.377+0.036$ \\
\hline 6 & $74.2+0.6$ & $6.2+0.24$ & $30+1$ & $0.404+0.019$ \\
\hline 7 & $75.1+0.2$ & $6.1+0.16$ & $31+2$ & $0.413+0.025$ \\
\hline 8 & $76.2+0.1$ & $5.9+0.18$ & $33+2$ & $0.433+0.027$ \\
\hline 9 & $76.1+0.3$ & $5.9+0.03$ & $34+1$ & $0.447+0.030$ \\
\hline
\end{tabular}

Table 3 Physical properties of bread

Source: Self Made
It can be seen that in terms of weight results, the formulations that had the greatest weight are those that had the highest CMC content due to the retention capacity of the water compound. According to the work done by Wongklom et al. (2016), it was observed that the highest water retention is in breads with carboxymethyl cellulose as water retainer. Similarly, it can be observed that as the carboxymethyl cellulose content increases and the amount of chickpea flour the specific volume increases forming a more compact flour since the soluble fiber of the chickpea acts as a water retainer forming a gel which also It makes it functional for its in the elaboration of other products such as sausages (Sanjeewa, et al., 2010).

The chickpea (Cicer arietinum), belonging to the Cicereae family, is an annual herbaceous plant. After harvesting, the grains are regularly kept in fresh and ventilated places that favor drying, from which it is possible to convert them into flour, which in the Mediterranean and Indian countries is consumed in combination with pea flour (AEP, 2007 ). Chickpeas are considered a good source of protein due to their high concentration of free tryptophan (Tavano, da Silva, Demonte and Neves, 2008; Comai, Bertazzo, Costa and Allegri, 2011). Its use in the form of flour as a fortifying ingredient in wheat flour is being considered for the development of new products (Comai et al., 2011).

On the other hand, Agama-Acevedo et al. (2009) prepared different mixtures of banana flour and semolina $(15 \%, 30 \%$ or $45 \%$ banana flour, taking as a control, $100 \%$ semolina), for the elaboration of spaghetti. The total starch content was greater than $45 \%$, presenting lower content of available starch; in addition, it was observed that the content of resistant starch and the non-digestible fraction increased in relation to the amount of banana flour added. Additionally, these researchers showed that the hardness and elasticity of spaghetti were not affected by the addition of banana flour, but the adhesiveness and chewiness increased as the percentage of banana flour in the mixture increased. In addition, the different prepared spaghetti showed no preference differences among consumers (Agama-Acevedo et al., 2009). 


\section{Sensory evaluation}

The results of sensory evaluation are as follows (Figure 1)

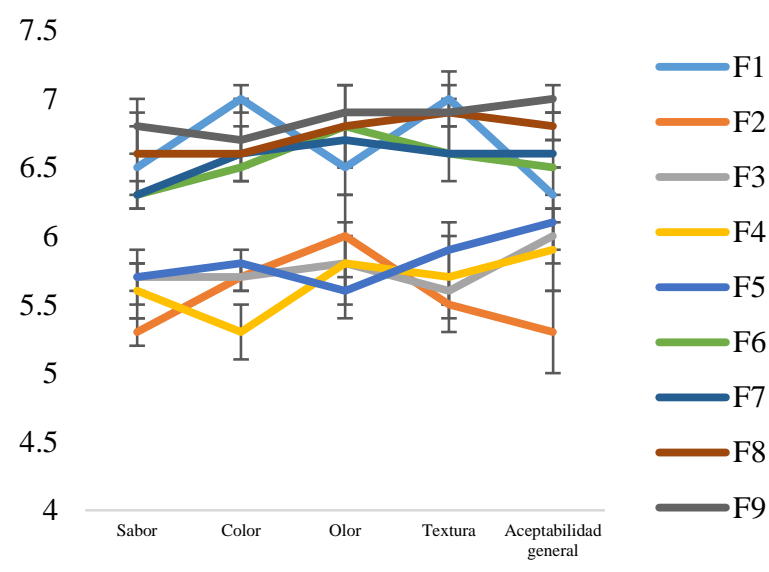

Graph 1 Results of the sensory evaluation Source: Self Made

It can be seen that with respect and in comparison with the standard formulation, the formulation with the highest CMC content and those with the highest banana flour content, have similar qualifications, even being in some points higher in the banana flour formulations being This is because the banana flavor conferred by banana peel flour was attractive to most panelists. Therefore, a significant difference (p $<0.05$ ) is observed between formulations with different amounts of CMC.

It has been proven in other studies conducted with bread formulation with flours enriched with vegetable or leguminous products have very attractive sensory characteristics for consumers since the added products contain light flavors that go well with any flavoring added to them (Osorio-Díaz, et al., 2008).

\section{References}

Abou, E, Helmy, I. y Bareh, G. (2010). Nutritional evaluation and functional properties of chickpea (Cicer arietinum, L.) flour and improved produced from its. Journal of American Science, 6(10), 1055-1072.

AEP (European Association for Grain Legume Research). (2007). The amazing lentil. Recuperado el 10 de febrero 2014. http://www.legumefutures.de/images/Grain_legumes_57_Lentils.pdf
Agama-Acevedo, E., Islas-Hernández, J., Osorio-Díaz, P., Rendón-Villalobos, R., UtrillaCoello R., Angulo, O. y Bello-Pérez, L. (2009). Pasta with unripe banana flour: physical, texture and preference study. Journal of Food Science, 74(6), 90-95.

Aguilar, N.; Albanell, E.; Miñarro, B.; Capellas, M. Chickpea and tiger nut flours as alternatives to emulsifier and shortening in gluten-free bread. LWT_Food Sci. Technol. 2015, doi:10.1016/j.lwt.2014.12.045.

Bello-Pérez, L., Agama-Acevedo, E., OsorioDíaz, P., Utrilla, R. y García, F. (2011). Banana and mango flours. En Preedy, V., Watson, R. y Patel, V. B. Flour and breads, and their fortification in health and diseases prevention. (Primera edición, págs. 235-244). San Diego, CA: Elsevier.

Comai, S., Bertazzo, A., Costa, C. y Allegri, G. (2011). Quinoa: protein and non-protein tryptophan in comparison with other cereal and legume flours and bread. En Preedy, V., Watson, R. y Patel, V. B. Flour and breads, and their fortification in health and diseases prevention. (Primera edición, págs. 113-125). San Diego, CA: Elsevier.

Comai, S., Bertazzo, A., Costa, C. y Allegri, G. (2011). Quinoa: protein and non-protein tryptophan in comparison with other cereal and legume flours and bread. En Preedy, V., Watson, R. y Patel, V. B. Flour and breads, and their fortification in health and diseases prevention. (Primera edición, págs. 113-125). San Diego, CA: Elsevier.

Demirkesen, I.; Mert, B.; Sumnu, G.; Sahin, S. Utilization of chestnut flour in gluten-free bread formulations. J. Food Eng. 2010, doi:10.1016/j.jfoodeng.2010.07.017.

Guemes-Vera, N., Bernardino-Nicanor, A., González, L., Totosaus-Sánchez, A. 2011. Effect of the addition of orange peel flour on the physicochemical characteristics of the texture profile analysis and sensory in bakery products and sausages. En Vargas D. y Medina, J. Citric Acid: synthesis, properties and applications. Nova Science Publishers, Inc: Reino unido. 
Hefnawy, T., El-Shourbagy, G. y Rmadan, M. (2012). Impact of adding chickpea (Cicer arietinum L.) flour to wheat flour on the rheological properties of toast bread. International Food Research Journal. 19(2), 521-525.

Jahreis, G., Brese, M., Leiter, M., Schafer, U., Böhm, V. 2015. Legume flours: Nutritionally important sources of protein and dietary fiber. Ernahrungs Umschau 63(2):36-42.

Juárez-García, E., Agama-Acevedo, E, SáyagoAyerdi, S., Rodrí- guez-Ambriz, S. y BelloPérez, L. (2006). Composition, digestibility and application in breadmaking of banana flour. Plant foods for human Nutrition, 61, 131-137

Ocampo-Olalde, R., Delgado-Suárez, E.J., Gutierréz-Pabello, J.A. 2015. Harina de cáscara de tuna como fuente de fibra y su efecto sobre las caracaterísticas fisicoquímicas y sensoriales de salchichas bajas en sodio y grasas. NACAMEH, 9(2): 54-65

Osorio-Díaz, P. Agama-Acevedo, E., MendozaVinalay, M., Tovar, J., Bello-Pérez, L.A. 2008. Pasta added with chickpea flour: cemical composition, in vitro starch digestibility and predicted glycemic index. SOMENTA. 6(1):612

Ovando, M. (2008). Pasta adicionada con harina de plátano: digestibilidad y capacidad antioxidante. Tesis de maestría no publicada. Instituto Politécnico Nacional, Morelos, México.

Pourafshar, S., RosentrateR, K.A., Padmanahan, G.K. 2015. Using alternative flours as partial replacement of barbari bread formulation Journal of Food Science and Technology, 52(9): 5691-5699.

Rosas, R., Goméz, N., Tomás, E., Hernández, A., Dorantes, J.D., García, B., Vázquez, G.A. 2018. Valorización de cáscaras de huevo como suplemento de calcio en pasta tipo Fetuccine. Boletín Científico del Instituto de Ciencias Básicas e Ingeniería, 10: 4-6.

Sanjeewa, W., Wanasundara J., Pietrasik, Z. y Shand, P. (2010). Characterization of chickpea (Cicer arietum L.) flour and application in lowfat pork bologna as a model system. Food Research International, 43, 617-626.
Sanjeewa, W., Wanasundara J., Pietrasik, Z. y Shand, P. (2010). Characterization of chickpea (Cicer arietum L.) flour and application in lowfat pork bologna as a model system. Food Research International, 43, 617-626.

Tavano, O., da Silva, S., Demonte, A. y Neves, V. (2008). Nutritional responses of rats to diets based on chickpea (Cicer arietinum L.) seed meal or its protein fractions. Journal of Agricultural and Food Chemistry, 56, 1100611010. 